\title{
PROSPECTS OF SAPROPELIC FLUIDS USE FOR OIL AND GAS WELLS DRILLING AND REPAIR
}

- • еонтьев, . у устышев, . . едрик

D. S. Leontev, A. V. Kustyshev, N. S. Cedric

юменский индустри льный университет, г. юмень

$$
\begin{gathered}
\text { лючевые слов : с пропель; р створ; нефтяные и г зовые скв жины; бурение; ремонт } \\
\text { Key words: sapropel; mud; oil and gas well; drilling; repair }
\end{gathered}
$$

последние 5-10 лет в н шей стр не зн чительно вырос объем бурения глубоких скв жин, усложнились геолого-технические условия ( _ ) их проводки, что в свою очередь повысило требов ния к к честву буровых р створов. 
н ш взгляд, перспективны для их приготовления к устобиолиты, то есть природные орг ногенные м тери лы (с пропели, торфы и т. д.).

конце прошлого век проводились н учные исследов ния, которые пок 3 ли перспективность применения м логлинистых буровых р створов н основе ктивиров нного торф и с пропеля [1]. ч стности, проведены эксперимент льные исследов ния типичных низинных, переходных и верховых торфов п дной ибири н предмет использов ния их в к честве дисперсной ф зы буровых р створов.

сост в к устобиолитов входят основные компоненты, необходимые для получения р створов, используемых в бурении и ремонте нефтяных и г зовых скв жин. инер льн я сост вляющ я к устобиолитов предст влен тонкодисперсными глинистыми минер л ми, к рбон тными пород ми, окисл ми мет ллов. рг ническ я сост вляющ я к устобиолитов содержит комплекс высокомолекулярных соединений, в ч стности гуминовые соединения, легко- и трудногидролизуемые веществ , лигнин, битумы, углеводы, природные жирные кислоты, которые выполняют роль ст билиз торов минер льной сост вляющей. личие в сост ве с пропелей и торф орг номинер льных комплексов зн чительно увеличив ет структурообр зующую способность твердой ф зы и облегч ет процесс упр вления структурно-реологическими и технологическими свойств ми буровых р створов н их основе [2].

опрос об использов нии с пропелей в н родном хозяйстве был поднят впервые в , когд в сост ве омиссии по изучению естественных производительных сил при оссийской к демии н ук был обр зов н пропелевый комитет. то позволило в огромных м сшт б х н ч ть р боты по изыск нию и изучению с пропелей в р зличных р йон х стр ны. ем лов жное зн чение для пост новки p бот по исследов нию с пропелей внесл л бор тория с пропелевых отложений нститут лес и л бор тория генезис с пропелей нститут горючих ископ емых н чительный вкл д в изучение с пропелевых отложений внес нститут торф [3].

пропели предст вляют собой желеобр зную или зернистую м ссу от розового до коричнев то-оливкового и почти чёрного цвет . ри высых нии твердеют.

тери лом для обр зов ния с пропеля являются ост тки орг низмов, н селявших толщу донных отложений воды (фито- и зоопл нктон) и ее поверхность, высшие водные р стения (м крофиты) и продукты их р сп д, т кже поступ ющие с водосбор p створенные веществ и минер льные ч стицы. ормиров ние с пропеля происходит под воздействием биохимических, микробиологических и мех нических процессов. бр зов вшийся с пропель предст вляет собой сложный орг номинер льный комплекс веществ. сост в орг нического веществ , кроме р стительных и животных ост тков и продуктов их р сп д, входят продукты жизнедеятельности микроорг низмов. рг ническ я ч сть с пропелей содержит от 3 до $11 \%$ битумов, до $40 \%$ гуминовых веществ и других биологически ктивных веществ. инер льн я ч сть с пропелей ч ще предст влен глинистыми, песч нистыми и мелко левритовыми терригенными или к рбон тными ч стиц ми. минер льном сост ве выделяют: ллотигенные минер лы - кв рц, к лиевые полевые шп ты, пл гиокл зы, биотит, мусковит и др.; сингенетические утигенные минер лы - оп л, к льцит, лимонит, сидерит, гипс; ди генетические минер лы к льцит, сидерит, м рк зит, пирит, сер и др. [4].

лининским политехническим институтом было предложено обр б тыв ть с пропели щелочью, полученные продукты н зыв ть с пропелещелочными ре гент ми [3]. дн ко с пропели для получения т ких ре гентов должны иметь высокое содерж ние орг нических веществ с преобл д нием гуминовых соединений и миним льное количество минер льных примесей.

целью р сширения возможности применения с пропелей . . иштв н выдвинул идею использов ния с пропелей в к честве структурообр зующих доб вок в буровые р створы. ыло выявлено [3], что д же небольшие доб вки с пропелей в глинистые р створы бл гоприятно ск зыв ются н структурно-реологических и тех- 
нологических свойств х буровых р створов. последствии елорусск я геологор зведочн я экспедиция пр вления геологии впервые провел испыт ние естественных дисперсий с пропелей в к честве буровых р створов [5].

спользов ние дисперсий с пропелей для приготовления буровых р створов связ но с некоторыми трудностями при тр нспортировке их к мест м бурения скв жин, особенно в зимний период. оэтому были проведены исследов ния по p зр ботке способ получения буровых $\mathrm{p}$ створов из предв рительно высушенного порошкообр зного с пропеля. ри высушив нии торф и с пропель зн чительно теряют способность к н бух нию и диспергиров нию в воде [6].

ем лов жное зн чение приобрет ет и выбор н иболее оптим льного способ

сушки с пропелей. еобходимо, чтобы в процессе высушив ния орг ническое вещество с пропелей не подверг лось термоокислительной деструкции, ценные структурирующие свойств естественных с пропелей были сохр нены [3].

рименение с пропелевых р створов в к честве эмульсий

мульсионные р створы применяются при бурении мощных глинистых и глинисто-к рбон тных толщ горных пород.

личие в с пропелях природных высокомолекулярных соединений (гуминовые и гидролизуемые веществ , битумы, белки, углеводы, жирные кислоты и др.) и высокодисперсных окислов мет ллов и люмосилик тов созд ет бл гоприятные предпосылки для получения устойчивых эмульсий. сновной метод их получения - физико-химическое диспергиров ние, то есть когд тонкодисперсные ч стицы с пропелей со сложной микромоз ичной природой поверхности выступ ют в роли твердых эмульг торов и, сосредот чив ясь н гр нице р здел ф з, ст билизируют эмульсионную дисперсную систему.

целью получения прямых эмульсий в естественную с пропелевую дисперсию или дисперсию н основе сухого с пропеля при постоянном перемешив нии последов тельно вводят 0,2-0,5\% щелочи, 0,25-0,5\% люмок лиевых кв сцов или сернокислого желез , 3 тем 3-10 \% сырой нефти по объему [3, 5].

мульг тор ми нефти в дисперсиях с пропелей служ т к к поверхностноктивные веществ ( ), содерж щиеся в р створенном состоянии, т к и с ми ч стицы с пропелей.

о . . ебиндеру из р зличных ф кторов ст билиз ции эмульсий первое место прин длежит мех ническому ф ктору - прочности ст билизирующего слоя глобул [7].

ысокодисперсные ч стицы орг нической ч сти с пропелей сосредот чив ются н гр нице $\mathrm{p}$ здел ф з и созд ют прочные структуриров нные дсорбционные слои. оверхность более крупных глобул с пропелей имеет лиофильногидрофобный х р ктер, что облегч ет дсорбцию н поверхности глобул. лобулы с покрыв ющими их высокодисперсными ч стиц ми с пропелей обр зуют звенья структурных цепей и соединяют их узл ми, что приводит к созд нию жесткого и прочного простр нственного структурного к рк с [3].

ри введении м лых доб вок нефти (до $3 \%$ ) отмеч ется р зжижение пресной дисперсии с пропеля и снижение прочности структуры. дн ко по мере того к К нефть диспергируется в виде мельч йших к пель, и увеличив ется ее количество, происходит повышение пл стической вязкости, дин мического предельного н пряжения сдвиг . то есть результ т дсорбции с пропелевых ч стиц н поверхности обр зующихся нефтяных к пель и постепенной перестройки дисперсной системы с формиров нием к чественно новой структурной сетки [8].

рименение с пропелевых р створов в к честве буферных жидкостей

ри строительстве глубоких скв жин цементиров ние - н иболее ответственный эт п, общие з тр ты по креплению скв жин достиг ют 20-30\% их общей стоимости. спех крепления в зн чительной степени з висит от эффективности очистки ствол от выбуренной породы и бурового р створ перед спуском обс дной колонны и цементиров нием. тсюд вытек ет необходимость р зр ботки высокоэффективных буферных (р зделительных) жидкостей. 
целью предупреждения з густев ния смесей буровых и т мпон жных р створов используют р зделительные буферные жидкости. х 3 к чив ют в скв жину перед т мпон жным р створом для предупреждения их смешив ния с буровыми р створ ми в обс дных труб х и з колонной, т кже для более полного вытеснения из з трубного простр нств ост тков бурового р створ [9].

к честве буферных жидкостей обычно используют р створы полимеров, , солей, кислот, нефть и др. ри выборе буферных жидкостей для конкретных геолого-технических условий необходимо в специ лизиров нной л бор тории проверить их совместимость с буровыми и т мпон жными р створ ми.

сновным критерием совместимости т ких р створов служит постоянство реологических свойств буферной жидкости после введения в нее буровых и т мпон жных р створов. этой связи необходимо проверить совместимость дисперсий с пропелей р зличных генетических типов с буровыми и т мпон жным р створ ми. ля этого дисперсии с пропелей смешив ют с глинистыми и меловыми р створ ми, т кже т мпон жными смесями при $/=0,5$, после чего для исходных р створов и их смесей определяют реологические х р ктеристики [3]. тмечено, что при смешив нии дисперсий с пропелей с бентонитовыми р створ ми не н блюд ется з густев ние смеси, в некоторых случ ях отмеч ется и д же р зжижение.

связи с высокой стойкостью с пропелей к полиминер льной грессии [10] были р зр бот ны сост вы буферных жидкостей н с пропелевой основе и p cтворов минер льных солей р зличной концентр ции. т ких буферных жидкостях с пропели выполняют роль структурирующих доб вок, которые прид ют им определенные структурно-реологические свойств .

сновное достоинство с пропелевых буферных жидкостей - их пригодность для д льнейшего использов ния в к честве буровых р створов после некоторой химической обр ботки.

собого вним ния з служив ет применение с пропелей в к честве доб вки в цементные р створы. ст новлено, что цементные р створы с доб влением с пропеля или торф обл д ют высокой коррозионной стойкостью к действию пл стовых вод, тем с мым увеличив я долговечность скв жин.

од руководством . . л бурды в елорусском н учно-исследов тельском геологор зведочном институте $\mathrm{p}$ зр бот ны сост вы цементно-торфяных и цементно-с пропелевых т мпон жных р створов [3,5]. об вление в сост в цементных $\mathrm{p}$ створов с пропелей и торф д ет возможность получ ть облегченные т мпон жные р створы, пригодные для цементиров ния в условиях ном льно низких пл стовых д влений ( ).

об вление с пропелей и торф р зличной плотности позволяет регулиров ть плотность т мпон жных р створов в довольно широких предел х. тмечено, что т мпон жные цементы при водоз творении в первый момент д ют ко гуляционнокрист ллиз ционные структуры небольшой прочности. д льнейшем в результ те ср ст ния и твердения цементных ч стиц прочность крист ллиз ционной структуры н р ст ет, тем с мым обр зуется прочный цементный к мень.

вторы т кже ктивно 3 ним ются р зр боткой новых м тери лов н основе природных орг ногенных м тери лов. к, к примеру, уже р зр бот н торфощелочной р створ для бурения скв жин в интерв л х, сложенных глинистыми пород ми и многолетнемерзлыми пород ми ( ). створ включ ет торф, щелочной модифик тор, ингибитор, флокулянт и воду. отличие от ближ йшего н лог он дополнительно содержит понизитель водоотд чи и пеног ситель, причем в к честве понизителя водоотд чи применяется полимер Polydia, в к честве ре гент снижения пенообр зов ния — пеног ситель огутов -200 [11].

зр бот н торфощелочной буровой р створ для вскрытия продуктивных пл стов, который включ ет в себя: торф, к лийносодерж щий щелочной модифик тор, полимер, утяжелитель, пеног ситель, см зыв ющую доб вку и воду. 
кже вторы р зр бот ли вязкоупругий сост в при проведении ремонтных $\mathrm{p}$ бот в скв жин х, который включ ет в себя: торф, к лийносодерж щий щелочной модифик тор, хлористый к лий, полимер, утяжелитель, пеног ситель и воду.

р бот х к демик ел руси . . иштв н пок з но, что применение с пропелей республики ел русь в некоторых случ ях позволяет добиться получения более высокок чественных дисперсных ф з по ср внению с торфом $[3,5]$.

н ш взгляд, торфы и с пропели юг юменской обл сти могут предст влять интерес для получения новых химических ре гентов для получения буровых р створов.

к федре « урение нефтяных и г зовых скв жин» юменского индустри льного университет для р звития н р боток белорусских ученых проведен комплекс исследов ний, н пр вленных н оценку возможности использов ния природных з п сов с пропелей юменской обл сти, н примере проб из озер ошк ринк , в к честве основы для р зр ботки буровых ре гентов и в перспективе созд ния с пропелевых буровых р створов.

зеро ошк ринк н ходится в 30 км н северо-восток от город юмень, рядом с деревней ияги. лощ дь озер сост вляет $\approx 42$ г, длин $-0,74$ км, ширин $-0,7 \mathrm{KM}$, средняя глубин $-2,7$ м, озеро имеет вытянутую с северо-восток н юг форму. од - сл бощелочн я, солевой сост в предст влен гидрок рбон т ми; минер лиз ция сост вляет 0,2 г/л. зеро имеет дост точно мощные донные отложения с пропелей от 0,4 м до 10 м, которые относятся к орг ническому типу.

етодик приготовления с пропелевых р створов 3 ключ л сь в следующем: н веску вл жного с пропеля определенной м ссы помещ ли при перемешив нии в 1000 мл воды, содерж щей р зличные концентр ции гидроксид к лия ( ). осле этого проводились измерения технологических п р метров полученной суспензии.

первон ч льном эт пе исследов ний был проведен оценк структурообр зующей способности с пропелевой суспензии путем определения условной вязкости р створов. олученные результ ты позволили сдел ть вывод, что увеличение концентр ции с пропеля и времени выдержки р створ ведет к повышению условной вязкости.

целью изучения возможности получения более к чественного бурового р створ из с пропеля изучено воздействие щелочи н суспензию. величение концентр ции щелочи не приводит к повышению условной вязкости. ем не менее н блюд ется рост с увеличением времени выдержки р створ .

еобходимо отметить, что полученные р створы обл д ют высокими зн чениями фильтр ции. целью снижения д нного пок з теля был проведен термическ я ктив ция полученных суспензий. успензии н грев ли до темпер туры более $80^{\circ}$, и в течение одного ч с перемешив ли при неизменной темпер туре. осле термической обр ботки пок з тель фильтр ции снизился пр ктически в 1,5 p 3 .

роведенные исследов ния пок з ли перспективность использов ния с пропеля в к честве дисперсной ф зы буровых р створов. д льнейшем пл нируется продолжить исследов ния суспензий н основе с пропеля, их модифик цию и ктив цию. л нируется для оценки эффективности р зр б тыв емых сост вов с пропелевого бурового р створ провести исследов ния н определение степени воздействия бурового $\mathrm{p}$ створ н фильтр ционно-емкостные свойств пород коллекторов в условиях, моделирующих пл стовые. роме того, необходимо в сост в с пропелевых буровых р створов вводить определенные концентр ции полимер , что потребует дополнительного изучения особенностей процессов структурообр зов ния т ких дисперсий в з висимости от степени высушив ния, концентр ции твердой ф зы, химических доб вок и других ф кторов.

ким обр зом, з последние годы в оссии зн чительно вырос объем бурения глубоких скв жин, усложнились геолого-технические условия их проводки, что и повыш ет требов ния к к честву буровых р створов. н ш взгляд, перспективны 
для их приготовления к устобиолиты — природные орг ногенные м тери лы (с пропели и торфы).

роведенные н учные исследов ния пок з ли перспективность использов ния с пропеля в к честве дисперсной ф зы буровых р створов.

писок литер туры

1. лияние тип и группового сост в торф н свойств буровых р створов / . . слов, . . олгих, . . убик, . . одунов // имия р стительного сырья. - 2003.- № 3. - . 57-67.

2. иштв н . ., ороль . . сновные свойств торф и методы их определения. - н., 1975.

3. ос ревич . . и др. пропелевые буровые р створы / . . ос ревич, . . итюков, . . . м вонянц.

од ред. . . иштв н . - н.: ук и техник , 1987. -191 с.

4. ирясов . ., иштв н . . ерер ботк и исследов ние торф и с пропелей. - н.,1971.

5. л бурд и . . и др. // собенности технологии строительств нефтяных скв жин в елоруссии // . . л бурд, . . м вонянц, . . иштв н. - н., 1980.

6. зин . . и др. // рименение торф и продуктов его химической перер ботки в н родном хозяйстве // . . зин, . курин , . б ров . - линин, 1980.

7. ебиндер . .// р. ІІІ сесоюз. конф. по коллоид. химии. - $\quad .1967$.

8. убм н . ., орецкий . .// спехи коллоид. химии. - .: 1973.

9. урение нефтяных и г зовых скв жин: учебник для н ч. проф. обр зов ния / . . децкий. - $\quad$. к демия, 2003. -352 с.

10. удинов . ., ос ревич . . // урение глубоких р зведочных скв жинн нефть и г з в елоруссии.- н., 1984.

11. т. 2550704,09 8/12 (2006.01). орфощелочной буровой р створ для бурения скв жин в многолетнемерзлых пород х / . . еонтьев, . . устышев, . . вчинников, . . кин ( ). - № 2014117048; 3 яв. 25.04.14; опубл. 10.05.15, бюл. № 13 .

ведения об втор $x$

еонтьев митрий ергеевич, спир нт, ссистент к федры « урение нефтяных и г зовых скв жин», юменский индустри льный университет, г. юмень, тел. 8(3452)200989, e-mail: leonfob@mail.ru

устышев лекс ндр сильевич, д. т. н., профессор к федры « урение нефтяных и г зовых скв жин», юменский индустри льный университет, г. юмень, тел. 8(3452)200989, е-таil: kustishev@tngg.info

едрик икол й ергеевич, ссистент $\kappa$ федры « урение нефтяных и г зовых скв жин», юменский индустри льный университет,

\section{Information about the authors}

Leontiev D. S., postgraduate, assistant of the chair «Drilling of oil and gas wells», Industrial University of Tyumen, phone: 8(3452)200989, e-mail:leonfob@mail.ru

Kustyshev A. V., Doctor of Engineering, professor of the chair «Drilling of oil and gas wells», Industrial University of Tyumen, phone: 8(3452)200989, e-mail: kustishev@tngg.info

Cedric N. S., assistant of the chair "Drilling of oil and gas wells», Industrial University of Tyumen, phone: 8(3452)200989 